\title{
Postnatal Surge in Serum Calcitonin Concentrations: No Contribution to Neonatal Hypocalcemia in Infants of Diabetic Mothers
}

\author{
FRANCIS MIMOUNI, JEFFREY L. LOUGHEAD, REGINALD C. TSANG, AND JANE KHOURY \\ Department of Pediatrics, Division of Neonatology, Department of Internal Medicine, Division of Epidemiology \\ and Biostatistics, University of Cincinnati College of Medicine, Cincinnati, Ohio 45267-0541
}

\begin{abstract}
It has been suggested that hypercalcitoninemia may contribute to neonatal hypocalcemia in infants of diabetic mothers (IDM). Because the role of calcitonin (CT) in Ca metabolism in humans is questionable, we hypothesized that serum CT peaks similarly after birth in IDM and controls and that serum Ca concentrations do not correlate with serum CT. Forty-seven term IDM (White classes B-RT) were compared with 31 controls. Controls were born after normal pregnancies, labors, and deliveries. Blood samples (cord and $24 \mathrm{~h}$ ) were analyzed for $\mathrm{Ca}, \mathrm{Mg}$, parathyroid hormone (PTH), and CT. Repeated measures analysis showed increasing serum $\mathrm{Mg}$, PTH, and CT, and decreasing Ca over time. The incidence of hypocalcemia was significantly higher in the diabetic group $(p<0.01)$ and the incidence of hypomagnesemia was borderline significantly higher $(p<0.06)$. There were no differences in cord or 24-h serum concentrations of CT between groups. In multiple regression analysis, serum $\mathrm{Ca}$ and PTH were correlated $\left(p<0.02, R^{2}=0.33\right)$, but not serum Ca and CT; the increase in serum PTH in relation to serum $\mathrm{Ca}$ at the nadir $(24 \mathrm{~h})$ correlated directly with serum $M g$ concentrations $\left(R^{2}=0.31, p<0.05\right)$. Thus, serum CT increases after birth irrespective of the rate of decrease of serum Ca in both IDM and controls; high CT concentrations observed after birth (as compared with adult norms) do not seem to play a role in the pathogenesis of neonatal hypocalcemia in IDM; and responsiveness of parathyroid gland at birth is adversely affected by hypomagnesemia, which supports the theory of functional hypoparathyroidism in Mg deficiency. (Pediatr Res 28: 493495, 1990)
\end{abstract}

\section{Abbreviations}

IDM, infant of diabetic mother

CT, calcitonin

PTH, parathyroid hormone

NHC, neonatal hypocalcemia

IDM are at high risk for NHC, which may occur in up to $50 \%$ of these infants (1). Perinatal asphyxia and prematurity, wellknown risk factors for $\mathrm{NHC}$, also occur at high incidence in IDM

Received March 28, 1990; accepted July 2, 1990.

Correspondence: Francis Mimouni, M.D., Department of Pediatrics, Division of Neonatology, University of Cincinnati Medical Center, 231 Bethesda Avenue, Cincinnati, OH 45267-0541.

Supported in part by NIH Grant HD 11725, USPHS Training in Perinatal Care and Research Grant MCH MCT 000174, NIH Clinical Research Center Grant RR00068. NIH Grant HD 20748, the Perinatal Research Institute, and a grant from the Gerber Products Company.
$(2,3)$. However, it was shown in a prospective, matched-control study that NHC in IDM is significant even after controlling for the aforementioned variables (1). Leading theories related to the pathophysiology of NHC in IDM include: 1) maternal-fetal Mgdeficient state, due to maternal glycosuria (4), leading to fetal hypoparathyroidism and subsequent $\operatorname{NHC}(1,5)$ and 2$)$ neonatal hypercalcitoninemia $(6,7)$. The latter theory is supported by evidence that the neonatal surge in serum CT concentrations found in normal neonates also occurs in IDM, which might seem inappropriate when one considers the concomitant decrease in serum $\mathrm{Ca}$. Studies supporting this theory were limited by small sample size, with only one showing an inverse correlation between serum $\mathrm{Ca}$ and $\mathrm{CT}$ concentrations in 11 IDM (6). We conducted this prospective study to determine whether CT plays any role in NHC in IDM when simultaneous measurements of serum $\mathrm{Mg}$ and $\mathrm{PTH}$ concentrations are taken into account.

\section{MATERIALS AND METHODS}

Patients. Since 1979, 47 full-term (37-41 wk gestation) infants of insulin-dependent diabetic mothers (White classes B-RT) (8) were prospectively studied as part of an NIH-funded program project grant, "Diabetes in Pregnancy." Preterm infants were excluded from this study because of the confounding influences of gestational age on neonatal calcium metabolism (1). The 47 IDM were compared with a group of 31 term infants of nondiabetic pregnant women [normal glucose challenge test at $28 \mathrm{wk}$ gestation (9)] born after uncomplicated pregnancies, labors, and deliveries. This study was approved by the Review Board on Investigations Involving Human Beings of the University of Cincinnati Medical Center Hospital. Written informed consent was obtained from one of the legal guardians of each infant before enrollment into the study.

The aims of glycemic control in diabetic pregnancy were a preprandial blood glucose concentration below $5.55 \mathrm{mmol} / \mathrm{L}$ $(100 \mathrm{mg} / \mathrm{dL})$ and a $90-\mathrm{min}$ postprandial blood glucose concentration below $7.71 \mathrm{mmol} / \mathrm{L}(140 \mathrm{mg} / \mathrm{dL})$. Pregnant patients were hospitalized when necessary to maintain these goals of glycemic control. Maternal blood glycosylated $\mathrm{Hb}_{1}$ contents were measured every 4 wk to determine if adequate glycemic control was achieved. Pre- or postprandial capillary glucose concentration was alternatively measured at each weekly visit. In each patient, pre- or postprandial blood glucose values were averaged over each trimester as mean pre- or postprandial blood glucose concentrations per trimester (10).

Data collection. Diabetes was categorized using the White classification (8). Blood samples were collected from infants in both groups at birth from a double-clamped segment of umbilical cord and at $24 \mathrm{~h}$ of life for determination of $\mathrm{Ca}, \mathrm{Mg}, \mathrm{PTH}$, and CT. Gestational age was calculated from the last menstrual period and confirmed within \pm 2 wk of Ballard score (10). We defined NHC, using the traditional definition supported by the data 
collected in our own laboratories (11) as a 24-h serum Ca concentration below $8 \mathrm{mg} / \mathrm{dL}$ and neonatal hypomagnesemia as a $24-\mathrm{h}$ serum $\mathrm{Mg}$ concentration below $1.6 \mathrm{mg} / \mathrm{dL}$ (12). Serum glucose was measured in all infants at $2 \mathrm{~h}$ of age.

Biochemical analyses. Serum $\mathrm{Ca}$ and $\mathrm{Mg}$ concentrations were measured by atomic absorption spectrophotometry (13). The normal pediatric range for $\mathrm{Ca}$ in our laboratory is 2.15 to 2.72 $\mathrm{mmol} / \mathrm{L}(8.6$ to $10.9 \mathrm{mg} / \mathrm{dL})$, with an interassay coefficient of variation of $1.2 \%$. The normal pediatric range for $\mathrm{Mg}$ is 0.70 to $1.02 \mathrm{mmol} / \mathrm{L}$ ( 1.7 to $2.5 \mathrm{mg} / \mathrm{dL}$ ) with an interassay coefficient of variation of $2.8 \%$. Serum PTH assay was performed by a modification of the RIA of Arnaud et al. (14) using an antiserum raised in guinea pig. The antibody recognizes the entire 1-84 molecule (15). The serum standard was obtained from a hyperparathyroid subject. The normal adult range, calculated using the maximum likelihood method (16), which statistically accounts for undetectable values, is 33 to $117 \mu \mathrm{LEq} / \mathrm{mL}$ in nonpregnant adults in our laboratory. The interassay coefficient of variation is $14 \%$. Serum CT concentration was measured by a modification of the RIA procedure described by Heath and Sizemore (17). Normal adult values are less than $107 \mathrm{pg} / \mathrm{mL}$, with intraassay and interassay coefficients of variation of 6 and $15 \%$, respectively. Pre- and postprandial capillary blood glucose concentrations were measured with a reflectance meter (Ames dextrometer, Ames Co., Elkhart, IN) that was calibrated weekly and the accuracy of which was verified every 4 wk with simultaneous sample measured in the University Hospital Clinical Chemistry Laboratory. Total blood glycosylated $\mathrm{Hb}$ was measured by Isolab column chromatography with an interassay coefficient of variation of $7.2 \%$ and a normal range of 5.5 to $8.5 \%$ (18).

Data analysis. Data were analyzed using the Statistical Analysis System (SAS Institute, Inc., Cary, NC). Continuous data were tested for normality and were analyzed using analysis of variance techniques and $t$ test for normal data and Wilcoxon test for nonnormally distributed data. Fisher's exact test was used for analyzing categorical variables. Multiple regression analysis was used to determine the relationship between neonatal serum $\mathrm{Ca}$ concentrations and serum $\mathrm{Mg}, \mathrm{PTH}$, and CT concentrations. Analysis of covariance was used to detect differences between the diabetic and nondiabetic groups with respect to these relationships. Linear regression was used to test a relationship between serum $\mathrm{Mg}$ concentrations and serum PTH or the ratio of the PTH surge over the Ca nadir (delta PTH/Ca). Delta PTH/Ca is defined as [PTH $(24 \mathrm{~h})]-\mathrm{PTH}$ (cord)/Ca $(24 \mathrm{~h})$. The delta $\mathrm{PTH} / \mathrm{Ca}$ ratio has been previously used to relate the PTH response to the lowest serum Ca concentration $(1,5)$. Data are expressed as mean $\pm \mathrm{SEM}$; a $p$ value of less than 0.05 was considered significant.

\section{RESULTS}

The demographic characteristics of the population studied (in terms of maternal age, age at diagnosis of maternal diabetes, White classification, gestational age, birth weight, and Apgar scores) are shown in Table 1. Indices of glycemic control in pregnancy are shown in Table 2.

Due to standard policy of delivery of IDM soon after $37 \mathrm{wk}$

Table 1. Demographic characteristics of study population*

\begin{tabular}{lccc}
\hline & IDM & Controls & \\
& $(n=47)$ & $(n=31)$ & Significance \\
\hline Gestational age (wk) & $38.1 \pm 0.2$ & $39.8 \pm 0.2$ & $p<0.01$ \\
Birth wt $(\mathrm{kg})$ & $3.6 \pm 0.69$ & $3.3 \pm 0.07$ & $p<0.01$ \\
White class B & $6(12.8)$ & NA $\dagger$ & \\
White class C & $18(38.3)$ & NA $\dagger$ & \\
White class D-RT & $23(48.9)$ & NA $\dagger$ & \\
\hline
\end{tabular}

* Data expressed as mean \pm SEM or $n(\%)$.

$\dagger$ Not applicable.
Table 2. Indices of glycemic control in diabetic pregnancies*

Trimester 1 Trimester 2 Trimester 3

\begin{tabular}{lccc}
\hline $\begin{array}{c}\text { Mean preprandial blood glucose } \\
\text { concentration }(\mathrm{mg} / \mathrm{dL})\end{array}$ & $125 \pm 7$ & $113 \pm 5$ & $122 \pm 5$ \\
$\begin{array}{c}\text { Mean postprandial blood glucose } \\
\text { concentration }(\mathrm{mg} / \mathrm{dL})\end{array}$ & $183 \pm 8$ & $151 \pm 7$ & $162 \pm 9$ \\
$\begin{array}{l}\text { Glycohemoglobin } \mathrm{A}_{1} \text { content } \\
(\%) \dagger\end{array}$ & $10.1 \pm 0.3$ & $8.2 \pm 0.2$ & $7.8 \pm 0.2$ \\
\hline
\end{tabular}

* Data are expressed as mean \pm SEM.

† Sampling time at $19 \mathrm{wk}, 26 \mathrm{wk}$, and at delivery, representing glycemic control during the 1st, $2 \mathrm{nd}$, and 3 rd trimesters, respectively.

Table 3. Mean $\pm S D$ serum $C a, M g, P T H$, and $C T$ in IDM and controls

\begin{tabular}{lccc} 
& $\begin{array}{c}\text { IDM } \\
(n=47)\end{array}$ & $\begin{array}{c}\text { Controls } \\
(n=31)\end{array}$ & Significance* \\
\hline $\mathrm{Ca}(\mathrm{mg} / \mathrm{dL})$ & & & \\
Cord & $10.3 \pm 1.1$ & $10.2 \pm 0.5$ & $\mathrm{NS}$ \\
$24 \mathrm{~h}$ & $8.6 \pm 0.9$ & $9.0 \pm 0.6$ & $\mathrm{NS}$ \\
Significance $\dagger$ & $<0.01$ & $<0.01$ & \\
$\mathrm{Mg}(\mathrm{mg} / \mathrm{dL})$ & & & \\
Cord & $1.77 \pm 0.26$ & $1.82 \pm 0.21$ & $\mathrm{NS}$ \\
$24 \mathrm{~h}$ & $1.87 \pm 0.28$ & $1.91 \pm 0.16$ & $\mathrm{NS}$ \\
Significance $\dagger$ & $<0.05$ & $<0.05$ & \\
PTH $(\mu \mathrm{LEq} / \mathrm{mL})$ & & & \\
Cord & $25 \pm 15$ & $35.9 \pm 22$ & $\mathrm{NS}$ \\
$24 \mathrm{~h}$ & $50.5 \pm 37.2$ & $50.5 \pm 23$ & $\mathrm{NS}$ \\
Significance $\dagger$ & $<0.01$ & $<0.01$ & \\
$\mathrm{CT}$ (ng/mL) & & & \\
Cord & $42 \pm 37$ & $58 \pm 90$ & $\mathrm{NS}$ \\
$24 \mathrm{~h}$ & $228 \pm 136$ & $220 \pm 130$ & $\mathrm{NS}$ \\
Significance $\dagger$ & $<0.01$ & $<0.01$ & \\
\hline
\end{tabular}

* IDM compared with control.

$\dagger$ Cord blood compared with 24-h values.

of gestation (term), these infants had a lower mean gestational age than control infants. Analysis of covariance, adjusting for this difference, revealed that, within the narrow gestational age range considered, the length of gestation had no significant impact on the biochemical and hormonal variables studied. Also, birth weight, which was significantly higher in IDM, was not a significant variable in covariance analysis.

Table 3 shows the mean serum $\mathrm{Ca}, \mathrm{Mg}$, PTH and CT concentrations in IDM and controls. Repeated measures analysis of variance showed significant differences in both groups over time (decreasing serum $\mathrm{Ca}$, increasing serum $\mathrm{Mg}, \mathrm{PTH}$, and CT concentrations). Mean serum $\mathrm{Ca}, \mathrm{Mg}, \mathrm{PTH}$, and $\mathrm{CT}$ did not significantly differ between groups at any time point. However, the incidence of neonatal hypocalcemia (serum Ca at $24 \mathrm{~h}<2.0$ $\mathrm{mmol} / \mathrm{L}$, or $8 \mathrm{mg} / \mathrm{dL})$ was significantly higher in IDM $(30 \%)$ than in controls $(3.2 \%)(p=0.003)$ and the incidence of neonatal hypomagnesemia (serum $\mathrm{Mg}$ at $24 \mathrm{~h}<0.66 \mathrm{mmol} / \mathrm{L}$, or $1.6 \mathrm{mg} /$ $\mathrm{dL})$ was borderline significantly higher in IDM $(10.6 \%)$ than in controls $(0.0 \%)(p=0.06)$.

We performed a multiple regression analysis in which all patients (IDM and controls) were included; serum Ca at $24 \mathrm{~h}$ (nadir) was the dependent variable, with serum $\mathrm{Mg}, \mathrm{PTH}$, and CT used as independent variables. This analysis showed that serum Ca correlated significantly only with serum PTH $\left(R^{2}=\right.$ $0.33, p<0.02)$. The extent of the postnatal PTH surge in relation to serum $\mathrm{Ca}$ at $24 \mathrm{~h}(\Delta \mathrm{PTH} / \mathrm{Ca})$ correlated significantly with serum $\mathrm{Mg}$ concentration at $24 \mathrm{~h}\left(R^{2}=0.31, p<0.05\right)$. There was no correlation between the nadir serum $\mathrm{Ca}$ and the lowest serum glucose concentration in the IDM group.

\section{DISCUSSION}

The exact physiologic role of CT in the perinatal period-or in any other period in life-is still poorly understood (19). 
Calcitonin has hypocalcemic effects by its combined action on bone and kidney. However, patients with medullary carcinoma of the thyroid may have considerable elevations of serum CT concentrations without detectable hypocalcemia (19). Furthermore, patients with thyroid dysgenesis, although having abnormal calcemic curves when submitted to a calcium load, do not have significant baseline elevation of serum $\mathrm{Ca}(20)$. There is no disease state due to isolated CT deficiency, although it has been recently suggested that such deficiency might lead to hypercalcemia in Williams syndrome (21). A surge in serum CT concentrations occurs at birth, despite the decreasing serum Ca concentrations that follow cord clamping and interruption of transplacental Ca transport. The serum CT values reached with this surge are higher than at any other period in life (22). The significance and potential physiologic role in this apparently paradoxical CT surge are unknown. Also, Klein et al. (23) observed that postnatal CT concentration from birth to 6 y of age paralleled the agerelated decline in rate of bone growth. They speculated that CT may play a role in bone growth or mineralization.

In our study, irrespective of the extent of decrease in serum $\mathrm{Ca}$, serum CT concentrations increased to very similar values in both groups and serum $\mathrm{Ca}$ concentrations did not correlate with serum CT concentrations. Bergman et al. (6) speculated that neonatal hypoglycemia in IDM might lead to increased glucagon secretion, and because glucagon is known to both lower serum $\mathrm{Ca}(24)$ and stimulate CT secretion (6), it might, theoretically, directly and indirectly cause neonatal hypocalcemia. A recent study from our group demonstrated that, in asphyxiated infants, there is an increased serum CT concentration (presumably stressinduced) and that postnatal serum Ca concentrations correlate inversely with serum CT concentrations (25). However, in the same study, serum CT did not correlate with serum glucagon. Furthermore, the glucagon response to hypoglycemia appears to be blunted in IDM because hypoglycemic and normoglycemic IDM have similar serum glucagon concentrations (26). There is a lower serum glucagon concentration in IDM compared with controls (27).

The PTH response to decreasing serum concentrations, assessed by the ratio $\Delta \mathrm{PTH} / \mathrm{Ca}$, correlated with serum $\mathrm{Mg}$ concentrations. This would support the theory of $\mathrm{Mg}$ deficiency as a cause of functional hypoparathyroidism in newborn infants (28). However, hypoparathyroidism might not be the only explanation for NHC in IDM. Because a relative resistance to PTH in $\mathrm{Mg}$ deficiency has also been documented in adults, in theory, resistance to PTH might also be involved (29).

We conclude that serum CT concentrations increase at birth in IDM and controls, irrespective of the degree of hypocalcemia. CT does not appear to play a significant role in the pathophysiology of NHC in IDM. However, our diabetic patients were particularly well controlled, in that their glycohemoglobin concentrations were within the normal range as early as the 2 nd trimester of pregnancy. Thus, one should raise the possibility that our conclusions may not hold in a poorly controlled group of diabetic patients.

\section{REFERENCES}

1. Tsang RC. Kleinman LI, Sutherland JM, Light IJ 1972 Hypocalcemia in infants of diabetic mothers: studies in calcium, phosphorus and magnesium metabolism and parathormone responsiveness. J Pediatr 80:384-395

2. Mimouni F, Miodovnik M, Siddiqi TA. Holroyde J, Tsang RC 1988 Perinatal asphyxia in infants of insulin-dependent diabetic mothers. J Pediatr 113:345353

3. Mimouni F, Miodovnik M, Siddiqi TA, Holroyde J, Tsang RC 1988 High premature labor rate in insulin dependent diabetes. Obstet Gynecol 72(2): $175-180$

4. Atchley DW 1933 On diabetic acidosis: detailed study of electrolyte balance following withdrawal and re-establishment of insulin therapy. J Clin Invest 12:297-311

5. Tsang RC, Strub R, Brown DR, Steichen JJ, Hartman C, Chen I-W 1976 Hypomagnesemia in infants of diabetic mothers: Perinatal studies. J Pediatr 89:115-119

6. Bergman L, Kjellmer I, Selstam V 1974 Calcitonin and parathyroid hormone: relation to early neonatal hypocalcemia in infants of diabetic mothers. Biol Neonate 24:151-160

7. Salle B, David L, Glorieux F, Delvin EE, Louis JJ, Troncy G 1982 Hypocalcemia in infants of diabetic mothers. Studies in circulating calciotropic hormone concentrations. Acta Paediatr Scand 71:573-577

8. White P 1974 Diabetes mellitus in pregnancy. Clin Perinatol 1:331-349

9. Lavin J, Barden TP, Miodovnik M 1981 Clinical experience with a screening program for gestational diabetes. Am J Obstet Gynecol 141:491-494

10. Ballard JL, Kazmaier-Novak K, Driver M 1979 A simplified score for assessment of fetal maturation of newly born infants. J Pediatr 95:769-772

11. Loughead JL, Mimouni F, Tsang RC 1988 Serum ionized calcium concentrations in the neonate. Am J Dis Child 142:516-518

12. Mimouni F, Tsang RC 1987 Disorders of calcium and magnesium metabolism. In: Fanaroff AA, Martin RJ (eds) Neonatal-Perinatal Medicine: Diseases of the Fetus and the Infant, 4th Ed. CV Mosby, St. Louis, pp 1077-1093

13. Sunderman Jr FW, Carrol TE 1963 Measurements of serum calcium and magnesium by atomic absorption spectrometry. Am J Clin Pathol 43:302312

14. Arnaud C, Tsao J, Littledike $T 1971$ Radioimmunoassay of human parathyroid hormone in serum. J Clin Invest 50:21-26

15. Chen W-Wen, Park HM, King LR, Bahr GK, Goldsmith RE 1974 Plasma immunoreactive parathyroid hormone response to ethylene diamine tetraacetic acid. J Nucl Med 15:763-769

16. Dincsoy MY, Tsang RC, Laskarzewski P, Chen MH, Chen I-W, Lo D. Donovan EF 1982 The role of postnatal age and magnesium on parathyroid hormone response during "exchange" blood transfusion in the newborn period. J Pediatr 100:277-283

17. Heath H, Sizemore GW 1977 Plasma calcitonin in normal men: differences between men and women. J Clin Invest 60:1135-1139

18. Kaplan LA, Cline D. Gartside P. Burstein S, Sperling MA, Stein EA 1982 Hemoglobin $A_{1}$ in hemolysates from healthy and insulin-dependent diabetic children, as determined with a temperature-controlled mini-column assay. Clin Chem 28:13-17

19. Clemens TL, Holick MF 1983 Recent advances in the hormonal regulation of calcium and phosphorus in adult animals and humans. In: Holick MF, Gray TK, Anast CS (eds) Perinatal Calcium and Phosphorus Metabolism. Elsevier, Amsterdam, pp 1-18

20. Carey DE, Jones KL, Parthemore JG, Deftos LJ 1980 Calcitonin secretion in congenital nongoitrous cretinism. J Clin Invest 65:892-895

21. Culler FL. Jones KL, Deftos LJ 1985 Impaired calcitonin secretion in patients with Williams Syndrome. J Pediatr 107:720-723

22. Hillman LS, Rojanasathit S, Slatopolsky E, Haddad JG 1977 Serial measurements of serum calcium, magnesium, parathyroid hormone, calcitonin, and 25-hydroxy vitamin D in premature and term infants during the first week of life. Pediatr Res 11:739-742

23. Klein GL, Wadlington EL, Collins ED, Catherwood BD, Deftos LJ 1984 Calcitonin levels in sera of infants and children: relations to age and periods of bone growth. Calcif Tissue Int 36:635-638

24. Elrad H, Bergstrom WH, Dagoglu T 1980 Glucagon-induced hypocalcemia in the rat: effects of maturation and insulin. Pediatr Res 14:216-220

25. Venkataraman PS, Tsang RC, Chen IW, Sperling MA 1987 Pathogenesis of early neonatal hypocalcemia: studies of serum calcitonin, gastrin, and plasma glucagon. J Pediatr 110:599-603

26. Knip M. Lautala P. Leppaluto J, Akerbon HK, Kouvaleinen K 1983 Relation of enteroinsular hormones at birth to macrosomia and neonatal hypoglycemia in infants of diabetic mothers. J Pediatr 103:603-607

27. Williams PR, Sperling MA, Racasa Z 1979 Blunting of spontaneous and alanine stimulated glucagon secretion in newborn infants of diabetic mothers. Am J Obstet Gynecol 133:51-56

28. Shaul PW, Mimouni F, Tsang RC, Specker BL 1987 Role of magnesium in neonatal calcium homeostasis: effects of magnesium infusion on calciotropic hormones and calcium. Pediatr Res 22(3):319-323

29. Estep H, Shaw WA, Watlington C 1969 Hypocalcemia due to hypomagnesemia and reversible parathyroid hormone unresponsiveness. J Clin Endocrinol Metab 29:842-848 